\title{
Evaluation of Coral Pathogen Growth Rates After Exposure to Atmospheric African Dust Samples
}

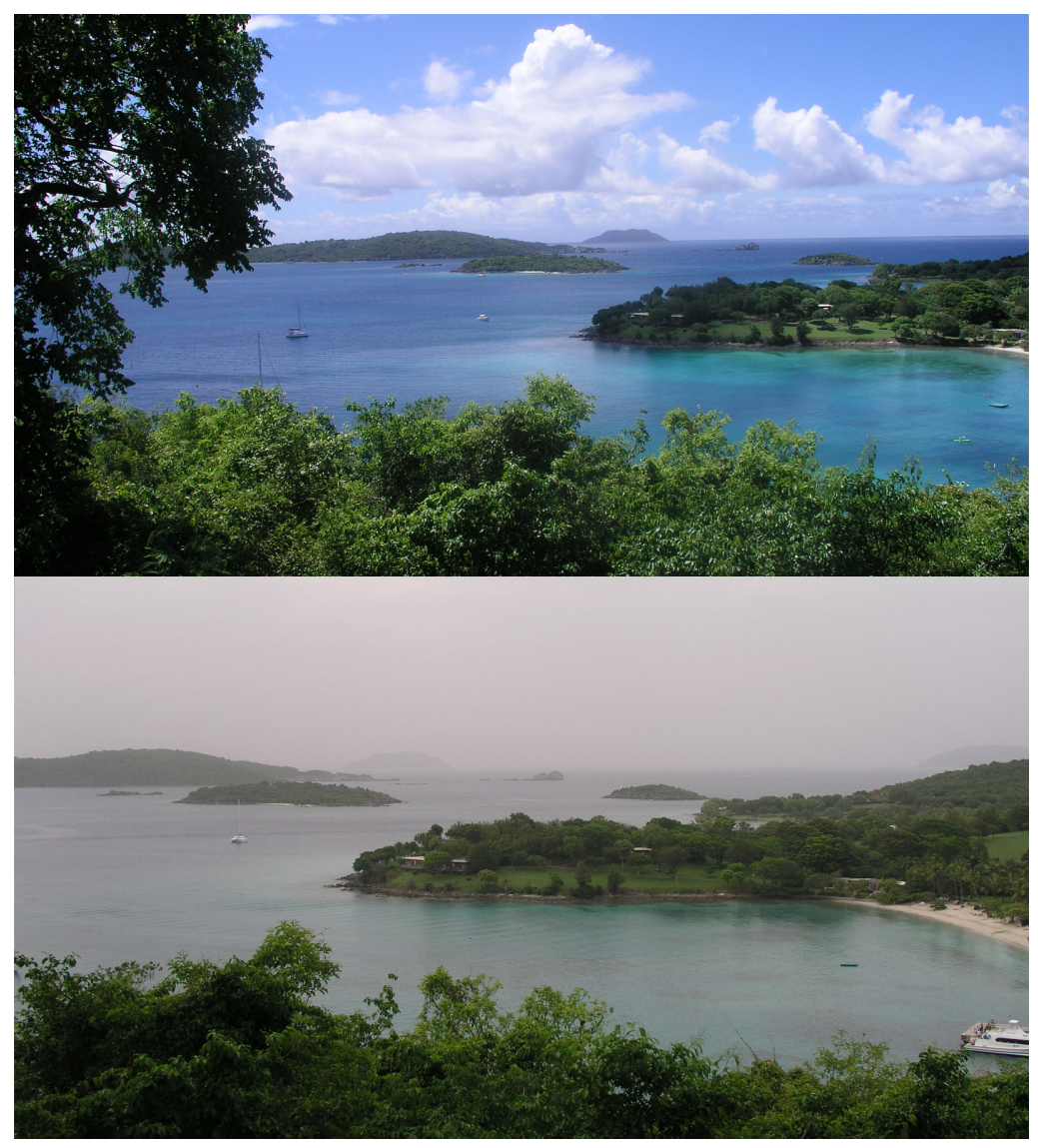

By John T. Lisle, Virginia H. Garrison, and Michael A. Gray

Open-File Report 2014-1017

U.S. Department of the Interior

U.S. Geological Survey 


\section{U.S. Department of the Interior SALLY JEWELL, Secretary}

\section{U.S. Geological Survey \\ Suzette M. Kimball, Acting Director}

U.S. Geological Survey, Reston, Virginia: 2014

For more information on the USGS-the Federal source for science about the Earth,

its natural and living resources, natural hazards, and the environment-visit

http://www.usgs.gov or call 1-888-ASK-USGS

For an overview of USGS information products, including maps, imagery, and publications, visit http://www.usgs.gov/pubprod

To order this and other USGS information products, visit http://store.usgs.gov

Any use of trade, product, or firm names is for descriptive purposes only and does not imply endorsement by the U.S. Government.

Although this information product, for the most part, is in the public domain, it also may contain copyrighted materials as noted in the text. Permission to reproduce copyrighted items must be secured from the copyright owner.

Cover photographs: From the Virgin Islands contrasting a clear day with a day on which a dust event occurred (Photo credit: Ginger Garrison, USGS).

Suggested citation:

Lisle, J.T., Garrison, V.H., and Gray, M.A., 2014, Evaluation of Coral Pathogen Growth Rates After Exposure to Atmospheric African Dust Samples: U.S. Geological Survey Open-File Report 2014-1017, 12 p., http://dx.doi.org/10.3133/ofr20141017

ISSN 2331-1258 (online) 


\section{Acknowledgments}

In-kind support from the following is greatly appreciated: in Mali, U.S. Embassy-Bamako, Ministry of Communication, Centre Nacionale Recherche Scientifique et Technologique, and ORTM Emetteur Kati; in the USVI, Dr. and Mrs. Richard Van Heckmann; and in Tobago, the Tobago House of Assembly.

The authors thank: the USGS Earth Surface Dynamics, Coastal and Marine Geology, and the Terrestrial, Aquatic, and Marine Ecosystems programs for funding the project; and Paul Lamothe (USGS, Denver, Colo.) for providing element analysis and Michael Majewski (USGS, Sacramento, Calif.) for heroics in the field in Tobago. 


\section{Contents}

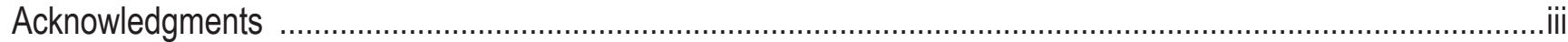

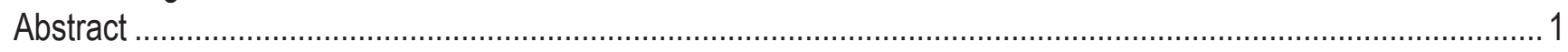

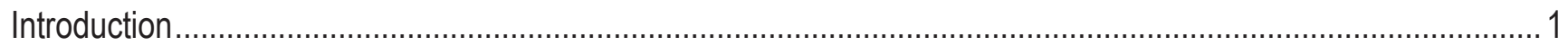

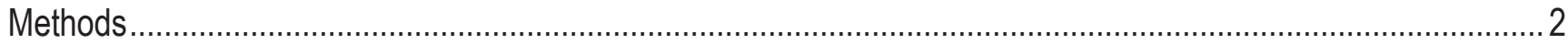

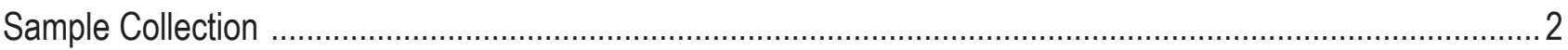

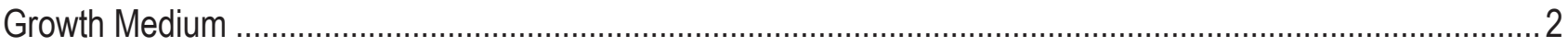

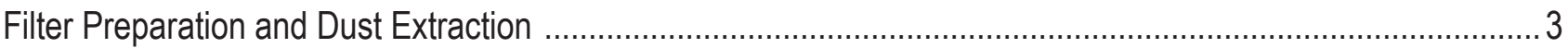

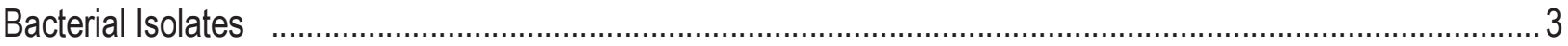

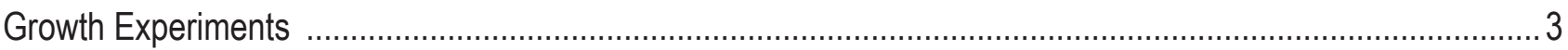

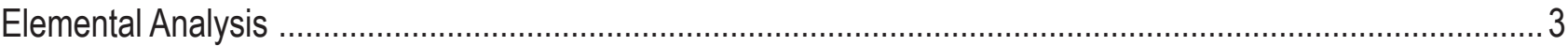

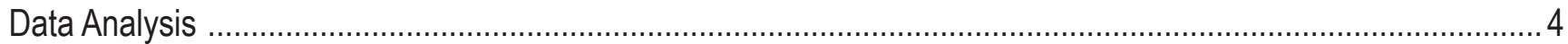

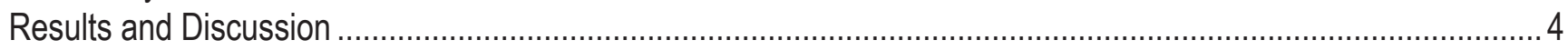

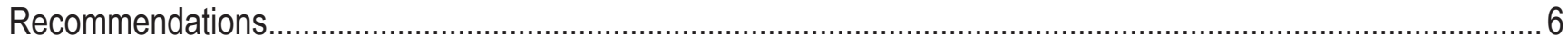

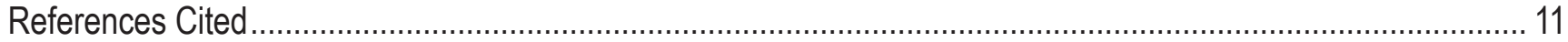

\section{Figures}

1. The effect of dust addition on the growth of Aurantimonas coralicida by site. ........................................ 7

2. The effect of dust addition on the growth of Vibrio shiloi by site........................................................... 8

3. The effect of dust addition on the growth of Serratia marcescens by site............................................. 9

4. The effect of dust addition on the growth of Vibrio coralliilyticus by site.............................................. 10

\section{Tables}

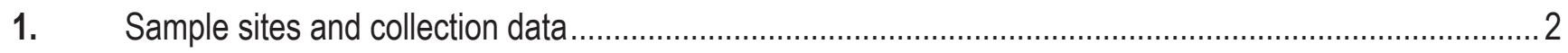

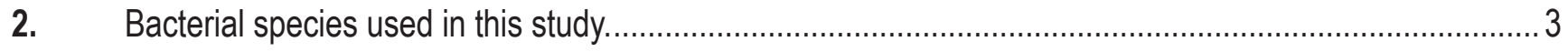

3. Linear regression models for log-phase segment of growth curves............................................... 5 
Conversion Factors

\begin{tabular}{lcl}
\hline Multiply & By & To obtain \\
\hline & Length & \\
\hline centimeter $(\mathrm{cm})$ & 0.394 & inch $(\mathrm{in})$. \\
millimeter $(\mathrm{mm})$ & 0.039 & inch (in.) \\
meter $(\mathrm{m})$ & 3.281 & foot $(\mathrm{ft})$ \\
kilometer $(\mathrm{km})$ & 0.621 & mile $(\mathrm{mi})$ \\
meter $(\mathrm{m})$ & 1.094 & yard $(\mathrm{yd})$ \\
\hline & Area & \\
\hline square centimeter $\left(\mathrm{cm}^{2}\right)$ & 0.001 & square foot $\left(\mathrm{ft}^{2}\right)$ \\
square meter $\left(\mathrm{m}^{2}\right)$ & 10.76 & square foot $\left(\mathrm{ft}^{2}\right)$ \\
square centimeter $\left(\mathrm{cm}^{2}\right)$ & 0.155 & square inch $\left(\mathrm{ft}^{2}\right)$ \\
\hline & Volume & \\
\hline liter $(\mathrm{L})$ & 33.82 & ounce, fluid $(\mathrm{fl}$. oz) \\
liter $(\mathrm{L})$ & 2.113 & pint $(\mathrm{pt})$ \\
liter $(\mathrm{L})$ & 1.057 & quart $(\mathrm{qt})$ \\
liter $(\mathrm{L})$ & 0.264 & gallon $(\mathrm{gal})$ \\
cubic meter $\left(\mathrm{m}^{3}\right)$ & 264.2 & gallon $(\mathrm{gal})$ \\
cubic meter $\left(\mathrm{m}^{3}\right)$ & 35.31 & cubic foot $\left(\mathrm{ft}^{3}\right)$ \\
cubic meter $\left(\mathrm{m}^{3}\right)$ & 1.308 & cubic yard $\left(\mathrm{yd} \mathrm{d}^{3}\right)$ \\
\hline & Mass & \\
\hline gram $(\mathrm{g})$ & 0.035 & ounce, avoirdupois $(\mathrm{oz})$ \\
kilogram $(\mathrm{kg})$ & 2.205 & pound avoirdupois $(\mathrm{lb})$ \\
\hline & Pressure & \\
\hline kilopascal $(\mathrm{kPa})$ & 0.010 & atmosphere, standard $(\mathrm{atm})$ \\
kilopascal $(\mathrm{kPa})$ & 0.1450 & pound per square inch $\left(\mathrm{lb} / \mathrm{in}^{2}\right)$ \\
\hline & Density & \\
\hline gram per cubic centimeter $\left(\mathrm{g} / \mathrm{cm}^{3}\right)$ & 62.4220 & pound per cubic foot $\left(\mathrm{lb} / \mathrm{ft}^{3}\right)$ \\
\hline
\end{tabular}

Temperature in degrees Celsius $\left({ }^{\circ} \mathrm{C}\right)$ may be converted to degrees Fahrenheit $\left({ }^{\circ} \mathrm{F}\right)$ as follows: ${ }^{\circ} \mathrm{F}=\left(1.8 \times{ }^{\circ} \mathrm{C}\right)+32$

Temperature in degrees Fahrenheit $\left({ }^{\circ} \mathrm{F}\right)$ may be converted to degrees Celsius $\left({ }^{\circ} \mathrm{C}\right)$ as follows: ${ }^{\circ} \mathrm{C}=\left({ }^{\circ} \mathrm{F}-32\right) / 1.8$ 


\title{
Evaluation of Coral Pathogen Growth Rates After Exposure to Atmospheric African Dust Samples
}

\author{
By John T. Lisle, Virginia H. Garrison, and Michael A. Gray
}

\begin{abstract}
Laboratory experiments were conducted to assess if exposure to atmospheric African dust stimulates or inhibits the growth of four putative bacterial coral pathogens. Atmospheric dust was collected from a dust-source region (Mali, West Africa) and from Saharan Air Layer masses over downwind sites in the Caribbean [Trinidad and Tobago and St. Croix, U.S. Virgin Islands (USVI)]. Extracts of dust samples were used to dose laboratory-grown cultures of four putative coral pathogens: Aurantimonas coralicida (white plague type II), Serratia marcescens (white pox), Vibrio coralliilyticus, and $V$. shiloi (bacteria-induced bleaching). Growth of $A$. coralicida and $V$. shiloi was slightly stimulated by dust extracts from Mali and USVI, respectively, but unaffected by extracts from the other dust sources. Lag time to the start of log-growth phase was significantly shortened for A. coralicida when dosed with dust extracts from Mali and USVI. Growth of $S$. marcescens and $V$. coralliilyticus was neither stimulated nor inhibited by any of the dust extracts. This study demonstrates that constituents from atmospheric dust can alter growth of recognized coral disease pathogens under laboratory conditions.
\end{abstract}

\section{Introduction}

African dust from the Sahara and Sahel of West Africa has been hypothesized to contribute to coral diseases through several mechanisms: transport of coral pathogens to downwind sites (Shinn and others, 2000); impairment of coral immune function or disease resistance from exposure to dust-associated synthetic organic contaminants, such as pesticides, polycyclic aromatic hydrocarbons, and polychlorinated biphenyls (Garrison and others, 2003); stimulation of microbial growth or alteration of coral resistance to pathogens from exposure to iron, trace metals, and nutrients associated with Saharan dust (Garrison and others, 2003); and induction of virulence factor expression in resident and (or) introduced microbes from exposure to iron, trace metals, and (or) nutrients in dust (Hayes and others, 2001; Garrison and others, 2003). Environmental factors have been reported to induce pathogenicity and to stimulate growth of coral pathogens. An increase in temperature $\left(\geq 25^{\circ} \mathrm{C}\right)$ has been shown to induce pathogenicity of the coral pathogens Vibrio coralliilyticus and V. shiloi (Toren and others, 1998; Kushmaro and others, 2001; Ben-Haim and others, 2003a, b). Remily and Richardson (2006) reported that higher temperatures $\left(25-35^{\circ} \mathrm{C}\right)$ increased the range of $\mathrm{pH}$ tolerance of Aurantimonas coralicida and suggested that response could facilitate colonization of the coral mucopolysaccharide layer, which has a relatively low $\mathrm{pH}$. Inorganic-nutrient (nitrate, ammonium, and phosphorus) dosing increased aspergillosis (infection by Aspergillus sydowii) severity, measured as tissue loss (Bruno and others, 2003). Thus, it is feasible that constituents of African dust may induce pathogenicity or virulence factors, and (or) stimulate growth of opportunistic pathogens regardless of their origin.

The objective of the pilot study reported here was to determine if the addition of African dust to laboratory-grown cultures of putative coral disease isolates stimulated or inhibited growth. The linear portions of the growth curves were compared to determine if the dust significantly increased, decreased, or had no effect on growth rates. 


\section{Methods}

\section{Sample Collection}

Air samples were collected from Kati, Mali, West Africa-a known dust source location (Gillies and others, 1996; McTainsh and others, 1997), and from two downwind sites: in the northwestern Caribbean [St. Croix, U.S. Virgin Islands (USVI)] and in the southeastern Caribbean (Tobago, Republic of Trinidad and Tobago; table 1). These downwind sites are historically impacted by dust originating from the Sahara Desert and Sahel region of Africa (Garrison and others, 2003). The origin of the collected dust was confirmed using model forecasts (Navy Aerosol Analysis and Prediction System, Global Aerosol Model of the Naval Research Laboratory, Monterey, California), satellite images, local atmospheric conditions, and iron ( $\mathrm{Fe}$ ) content and rare-earth element ratios [lanthanum (La), scandium ( $\mathrm{Sc}$ ), and thorium (Th); Muhs and others, 2007)] of the dust samples.

Table 1. Sample sites and collection data.

[masl, meters above sea level; $\mathrm{m}^{3}$, cubic meters; $\mathrm{mg}$, milligrams]

\begin{tabular}{llccccc}
\hline \multicolumn{1}{c}{ Sample site } & \multicolumn{1}{c}{ Date } & Latitude & Longitude & \multicolumn{2}{c}{ Site elevation } & Sample volume Aerosol mass \\
& & & & masl & $\mathbf{m}^{3}$ & mg \\
\hline Kati, Mali & April 4-6, 2008 & $12^{\circ} 41.28^{\prime} \mathrm{N}$ & $08^{\circ} 01.65^{\prime} \mathrm{W}$ & 555 & 1,852 & 431.0 \\
St. Croix, USVI & August 15-18, 2008 & $17^{\circ} 44.73^{\prime} \mathrm{N}$ & $64^{\circ} 35.15^{\prime} \mathrm{W}$ & 27 & 1,437 & 203.7 \\
Tobago & June 9-11, 2008 & $11^{\circ} 19.67^{\prime} \mathrm{N}$ & $60^{\circ} 32.50^{\prime} \mathrm{W}$ & 329 & 1,236 & 111.2 \\
\hline
\end{tabular}

Atmospheric dust was collected on 20.3 centimeters $(\mathrm{cm}) \times 25.4 \mathrm{~cm}$ quartz-fiber filters (Whatman Grade QM-A) that had been prebaked at $600{ }^{\circ} \mathrm{C}$ for 8 hours (h), cooled, and weighed. A high-volume blower motor, isolated from the filters, was used to draw air through the filters at 25-40 cubic meters $\left(\mathrm{m}^{3}\right) \mathrm{h}^{-1}$ for approximately $48 \mathrm{~h}$. At the completion of each sampling period, filters were removed, sealed in sterile polyethylene bags, and stored at $-20^{\circ} \mathrm{C}$. Subsequently, all filters were freeze-dried to remove moisture and until a constant weight was achieved and then stored at $-20^{\circ} \mathrm{C}$. Field blanks were collected for each site.

\section{Growth Medium}

Modified seawater-yeast extract medium [MSWYE; 1.0 gram $(\mathrm{g})$ peptone, $1.0 \mathrm{~g}$ yeast extract, $23.4 \mathrm{~g}$ sodium chloride $(\mathrm{NaCl}), 2.34 \mathrm{~g}$ magnesium sulfate $\left(\mathrm{MgSO}_{4}\right), 0.75 \mathrm{~g}$ potassium chloride $(\mathrm{KCl})$ per liter (L)] (Oliver and Colwell, 1973) was selected as the growth medium for all experiments. All laboratory glassware and plasticware used in the growth experiments were cleaned as follows: deionized water rinses (3x); 24-h soak in $2 \mathrm{~N}$ hydrochloric acid ( $\mathrm{HCl}$; trace-metals analysis grade); reagent-grade water rinses (3×); 24 -h soak in $3 \mathrm{~N}$ nitric acid $\left(\mathrm{HNO}_{3}\right.$; trace-metals analysis grade); reagent-grade water rinses $(3 \times)$; and 24-h soak in reagent-grade water. 


\section{Filter Preparation and Dust Extraction}

Prior to the initiation of the growth experiments, all filters were sterilized at $170{ }^{\circ} \mathrm{C}$ for $4 \mathrm{~h}$ to inactivate microorganisms (Harvard Biosafety, 2009). Subsequently, sample and control filters were placed in separate containers that contained $1.0 \mathrm{~L}$ of sterile MSWYE broth, incubated $\left[25{ }^{\circ} \mathrm{C}, 20 \mathrm{~min}-\right.$ utes (min)] to stimulate sporulation, and autoclaved [20.0 min at $121{ }^{\circ} \mathrm{C}, 20$ pounds per square inch (psi)]. Each sealed container was then placed on a rocking platform for $72 \mathrm{~h}$ to extract soluble constituents from the dust particles. Hereafter, this solution is referred to as the dust-extract solution. Control filters were handled identically, producing a "MSWYE-filter" extract to control for filter and medium effects.

\section{Bacterial Isolates}

Four bacterial isolates that have been implicated in one or more coral diseases and that could be grown in the laboratory with MSWYE were selected for testing their growth response following exposure to African dust (table 2). Despite repeated attempts, a fifth coral pathogen, Thalassomonas loyana (implicated in causing a white plague-like disease of corals in the Red Sea; Thompson and others, 2006), could not be grown.

Table 2. Bacterial species used in this study.

\begin{tabular}{llll}
\hline \multicolumn{1}{c}{ Bacterial species } & \multicolumn{1}{c}{ Coral disease } & \multicolumn{1}{c}{ Strain (source) } & \multicolumn{1}{c}{ Reference } \\
\hline Aurantimonas coralicida & White plaque (type II) & 14790 (DSMZ) & Denner and others, 2003 \\
Serratia marcescens & White pox & BAA-632 (ATCC) & Patterson and others, 2002 \\
Vibrio coralliilyticus & Bleaching & BAA-450 (ATCC) & Ben-Haim and others, 2003b \\
Vibrio shiloi & Bleaching & 13779 (DSMZ) & Kushmaro and others, 2001 \\
\hline
\end{tabular}

\section{Growth Experiments}

The experimental design consisted of dosing a culture of each bacterial isolate with an African dust extract in MSWYE medium and corresponding MSWYE-filter control (no dust extract added). Each experiment was performed in triplicate. For each experiment, 20.0 milliliters $(\mathrm{mL})$ of the respective dust-extract solutions were transferred to 20 -millimeter $(\mathrm{mm}) \times 150-\mathrm{mm}$ glass tubes. A volume $(1.0 \mathrm{~mL})$ of an overnight culture of the respective bacterial strains that had been grown in MSWYE at $25{ }^{\circ} \mathrm{C}$ with shaking [150 revolutions per minute $\left.(\mathrm{rpm})\right]$ was used for inoculation. All tubes were gently mixed, and the absorbance value $\left(\mathrm{Ab}_{0}\right)$ was immediately recorded using a spectrophotometer (590 nanometers). All experiments incubated the cultures at $25{ }^{\circ} \mathrm{C}$ in a shaking incubator $(150 \mathrm{rpm})$. Absorbance values $\left(A b_{t}\right)$ were recorded hourly for the first $10 \mathrm{~h}$, then twice daily for the following two days.

\section{Elemental Analysis}

Dust samples and field blanks were analyzed for $\mathrm{La}, \mathrm{Sc}$, Th, and Fe using inductively coupledplasma mass spectrometry (Briggs and Meier, 2002), instrumental neutron activation analysis, and (or) graphite-furnace atomic-absorption spectrometry. 


\section{Data Analysis}

All absorbance data were normalized to the time-zero absorbance values as a ratio (i.e., $\left.A b_{t} / \mathrm{Ab}_{0}\right)$. The normalized data were log-transformed and subsequently used to generate the respective growth curves for the complete incubation periods. The data used for the linear-regression models were selected from the linear segment of the total growth curve. The linear segments of the growth curves were then used to compare the growth rates (slopes) of dust-extract treated and corresponding filter control using the General Linear Model (GLM) for an analysis of covariance (Fry, 1993). The GLM was modified to test paired datasets used in the linear-regression models using the Tukey HSD method for pair-wise comparisons. The initial test was to determine if the slopes of the regression lines were parallel (i.e., equal) and, if so, if the intercepts were equal. If the slopes and intercepts of the treatment and control were statistically equal, the regression lines were considered coincident, representing no significant differences between bacterial growth rates in cultures exposed and not exposed to African dust extracts. All statistical analyses were conducted using Minitab (ver. 15; Minitab, Inc., State College, Pennsylvania).

\section{Results and Discussion}

There were minor, though statistically insignificant, stimulatory effects on pathogen growth when comparing the linear-regression data from the dust-extract solutions to that from the control cultures for A. coralicida $(\mathrm{p}=0.074)$ and $V$. shiloi $(\mathrm{p}=0.077)$, when dosed with dust extracts from Mali and USVI, respectively (table 3; figures 1-2). There were no significant differences between the growth rates of $V$. coralliilyticus or $S$. marcescens in control and dust-dosed cultures for all of the dust sources (table 3; figures 3-4).

Caveats that should be considered when interpreting the data from this study include the differences in dust sample masses collected at each site; the differences in particle sizes (and resulting bioaccessibility of bioactive elements) among sites; and the difficulty in extracting dust from the filter (quartz fiber) matrix. There were significant differences among the amounts of dust collected at Mali [0.23 milligrams $\left.(\mathrm{mg}) \mathrm{m}^{-3}\right]$, USVI $\left(0.14 \mathrm{mg} \mathrm{m}^{-3}\right)$, and Tobago $\left(0.09 \mathrm{mg} \mathrm{m}^{-3}\right.$; table 1$)$, a function of particle concentrations in the air masses sampled. Despite differences in dust mass collected at the three sites, elemental-analysis data confirmed an African origin for all samples ( $\mathrm{La}-\mathrm{Sc}-\mathrm{Th}$ ratios for samples and local soils). Concentrations of dust in Mali are orders of magnitude greater than in downwind sites, such as the Caribbean, 5,000 kilometers $(\mathrm{km})$ distant. Atmospheric-dust concentrations in Mali can exceed 13,000 microgram $(\mu \mathrm{g}) \mathrm{m}^{-3}$ with mean background concentrations of $575 \mu \mathrm{g} \mathrm{m}^{-3}$ (Gillies and oth-

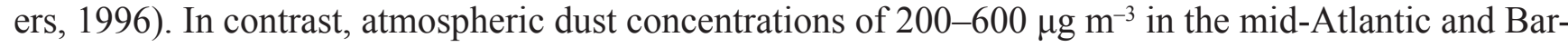
bados (Prospero and others, 1981; Talbot and others, 1986), 100-200 $\mu \mathrm{g} \mathrm{m}^{-3}$ in the Virgin Islands, and mean concentrations of 3-20 $\mu \mathrm{g} \mathrm{m}^{-3}$ in the Caribbean region have been reported (Prospero and Nees, 1986; Perry and others, 1997). Sample solutions were not normalized to milligrams per liter among the sites because the intent was to test for effects from real-world dust concentrations impacting a sitetrace element components as well as mass influx.

As the mass of dust particles decreases with increasing distance and time from the dust-source region, so does particle size. As the Saharan Air Layer exits the dust-source region, particles are lost via gravitational settling based on aerodynamic diameter and mass, such that primarily fine particles remain after approximately 5,000 km of atmospheric transport across the Atlantic Ocean to the Caribbean. The deposition of larger dust particles earlier in the transport process may provide a greater dose to marine systems closest to the African coast; however, the chemical composition of the dose could differ with 


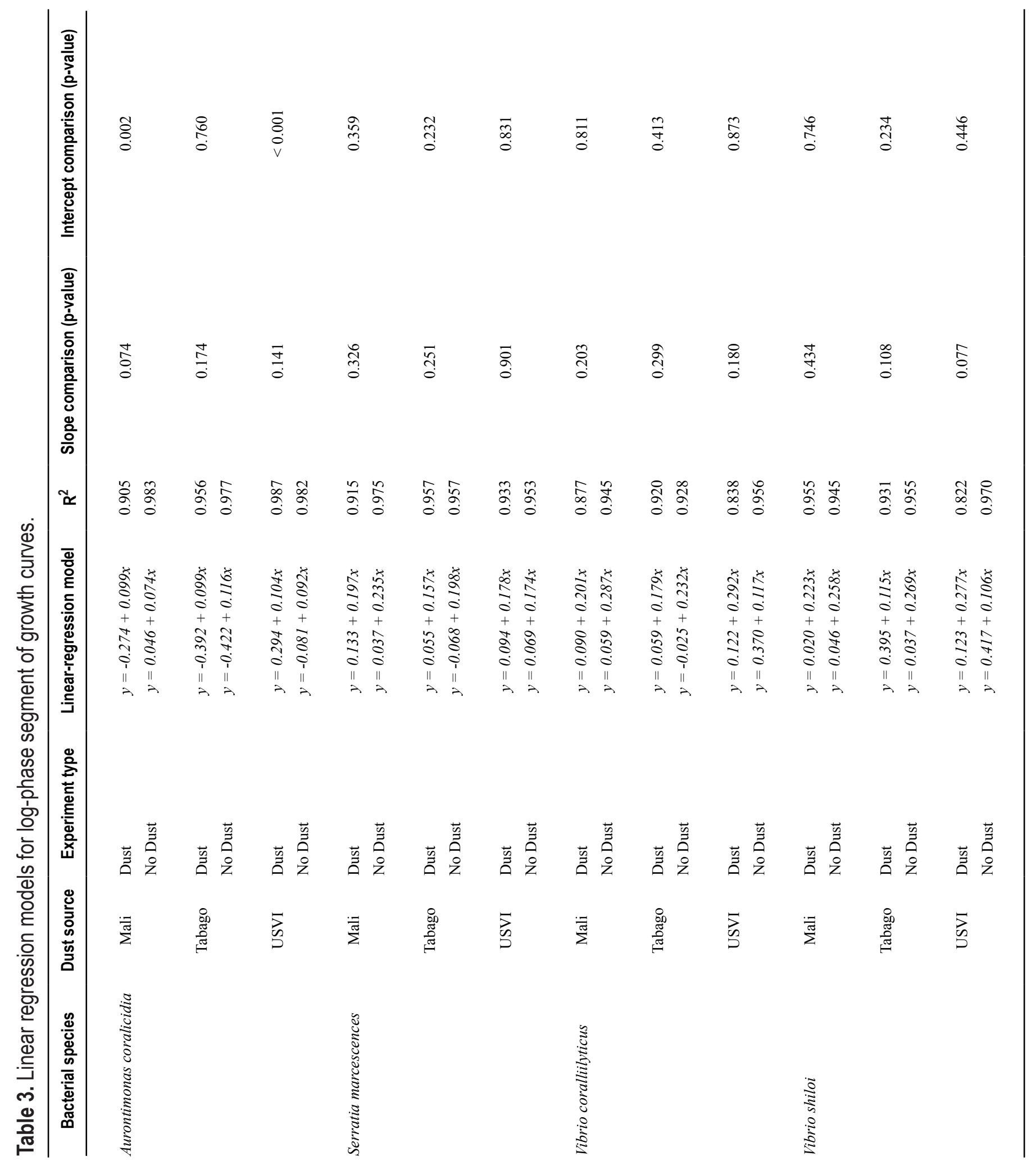


distance from the source region. The mineral and trace-element composition differs among particle-size fractions due to erosional processes, differences in parent mineral characteristics, and chemical and physical processes during long-distance atmospheric transport (Moreno and others, 2006; Castillo and others, 2008). Of greater biological significance, the biomobility and bioaccessibility of elements and cofactors have been shown to differ among atmospheric dust collected in Mali, Tobago, and the USVI, with bioactive elements generally more bioaccessible following long-distance transport to Tobago and USVI (Morman and others, 2013). Enhanced biomobility and bioaccessibility are likely a result of higher surface-area-to-volume ratios of fine particles that could enhance surface reactions and changes in the surface chemistry as a result of the extreme physical conditions of high-altitude long-distance transport, such as freeze-thaw cycles, exposure to UV, microbial activities, and atmospheric chemical reactions that could alter the surface components of the particles (Morman and others, 2013). The greater the distance from the dust-source region, the greater the duration of exposure to those conditions.

Removal of the dust particles from the quartz fiber matrix of the filters was problematic, and some dust was observed within filters following the 72-h extraction period. Whether dust particles were selectively retained as a function of size is unknown. In future studies, testing different filter matrices for particle-release is recommended prior to filter selection.

This study is the first to assess the influence that the constituents in African dust have on the growth of bacterial isolates that have been implicated in coral diseases. The data from these experiments indicate the growth of the coral disease pathogens, $A$. coralicida and $V$. shiloi, may be stimulated by African dust extracts. However, the absence of a growth response from the other bacterial strains following exposure to dust-extract solutions is not necessarily proof that African dust is nonstimulatory. Though this is a possibility, another explanation is that the dose-response thresholds for the other bacterial strains are higher than that of $A$. coralicida and $V$. shiloi and that the constituents in the dust extracts did not exceed those thresholds. The simple increase or reduction in biomass production and (or) response time to metabolizing available nutrients is not necessarily directly associated with the ability of a bacterial species to induce a disease response in its host. Either response would provide a selective advantage under natural conditions, providing an opportunity to dominate a niche on or in the host and initiate disease pathology. These preliminary findings indicate that further laboratory studies are needed to quantify and elucidate the effects of African dust on coral pathogens.

\section{Recommendations}

1. Culture conditions should be optimized to model those predicted in situ; for example, oligotrophic media or defined minimal media, temperatures in the range of those recorded at sea surface, and extended incubation times.

2. A culturability assay should be included from which a standard curve of absorbance versus colony forming units (CFU) can be constructed.

3. An assay should be included that measures changes in respiration rates; for example, ${ }^{14} \mathrm{C}$-labeled substrates that generate ${ }^{14} \mathrm{CO}_{2}$, should be incorporated. This would be useful because stimulatory effects of dust may produce an increase in respiration without an increase in bacterial productivity. 

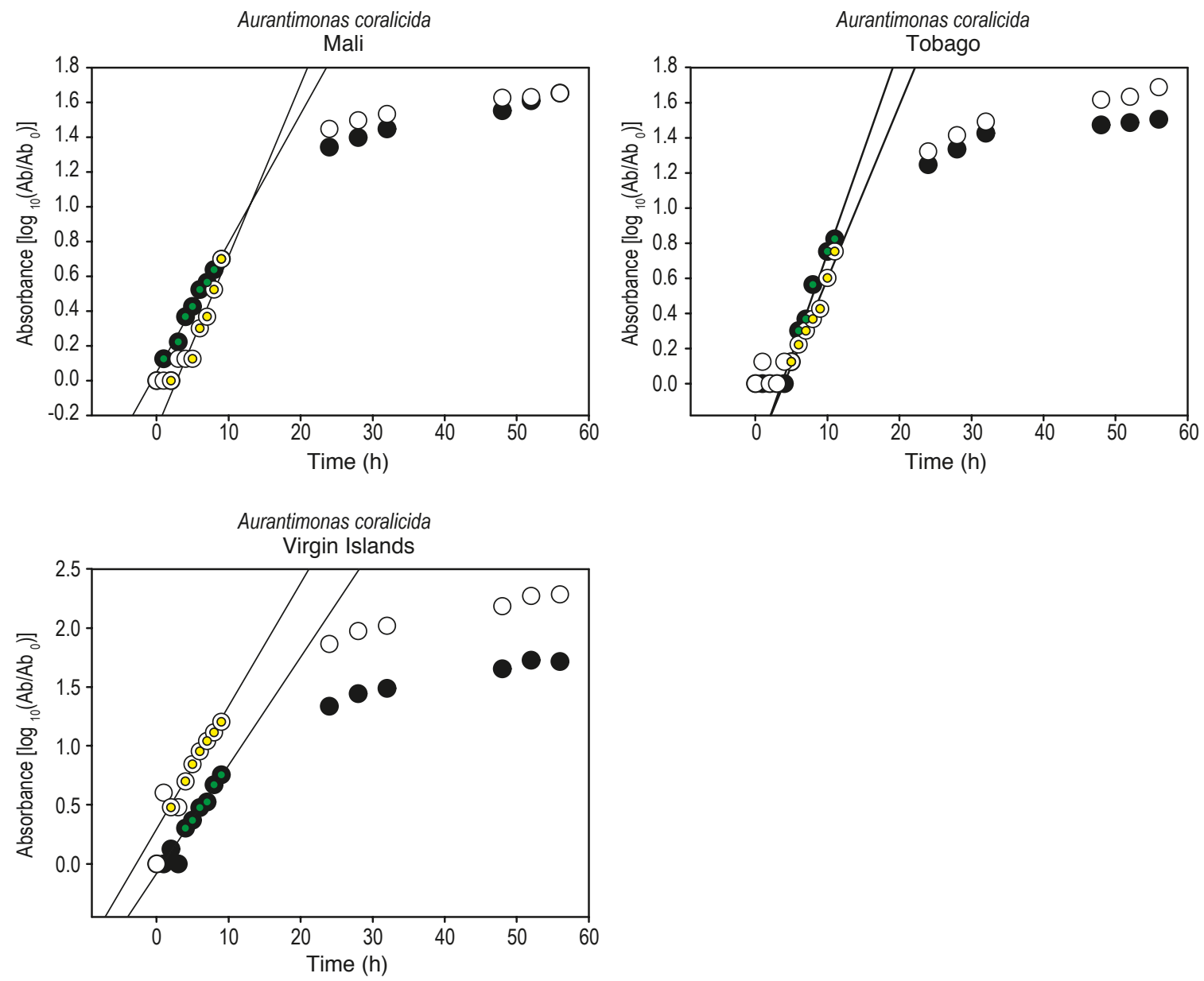

Figure 1. The effect of dust addition on the growth of Aurantimonas coralicida by site. The black symbols represent data for the filter control (i.e., no dust addition) culture and the white symbols represent data from the experimental (i.e., dust addition) culture. Those symbols with a colored center are the data values used in the calculations of the linear regression models. 

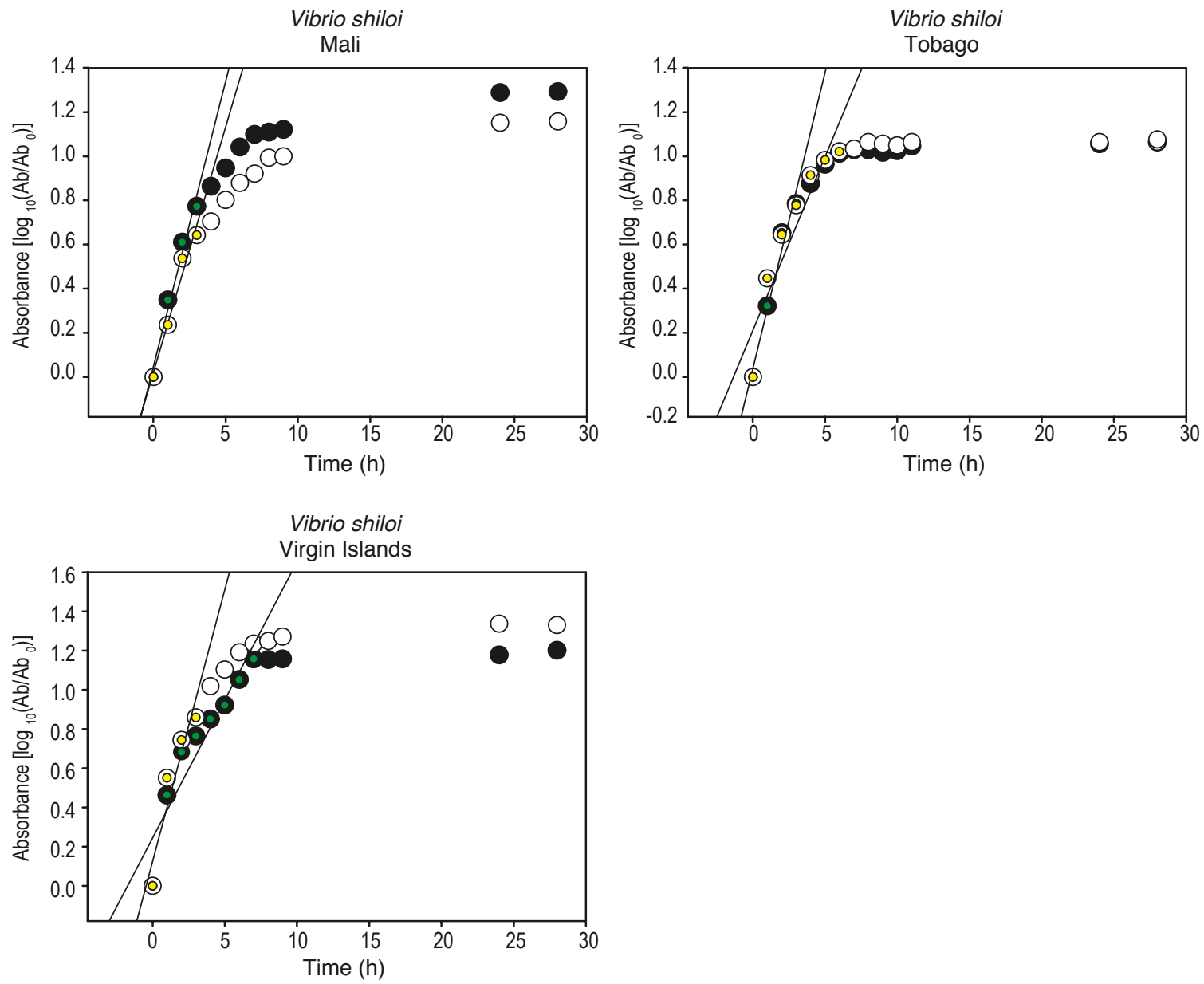

Figure 2. The effect of dust addition on the growth of Vibrio shiloi by site. The black symbols represent data for the filter control (i.e., no dust addition) culture and the white symbols represent data from the experimental (i.e., dust addition) culture. Those symbols with a colored center are the data values used in the calculations of the linear regression models. 

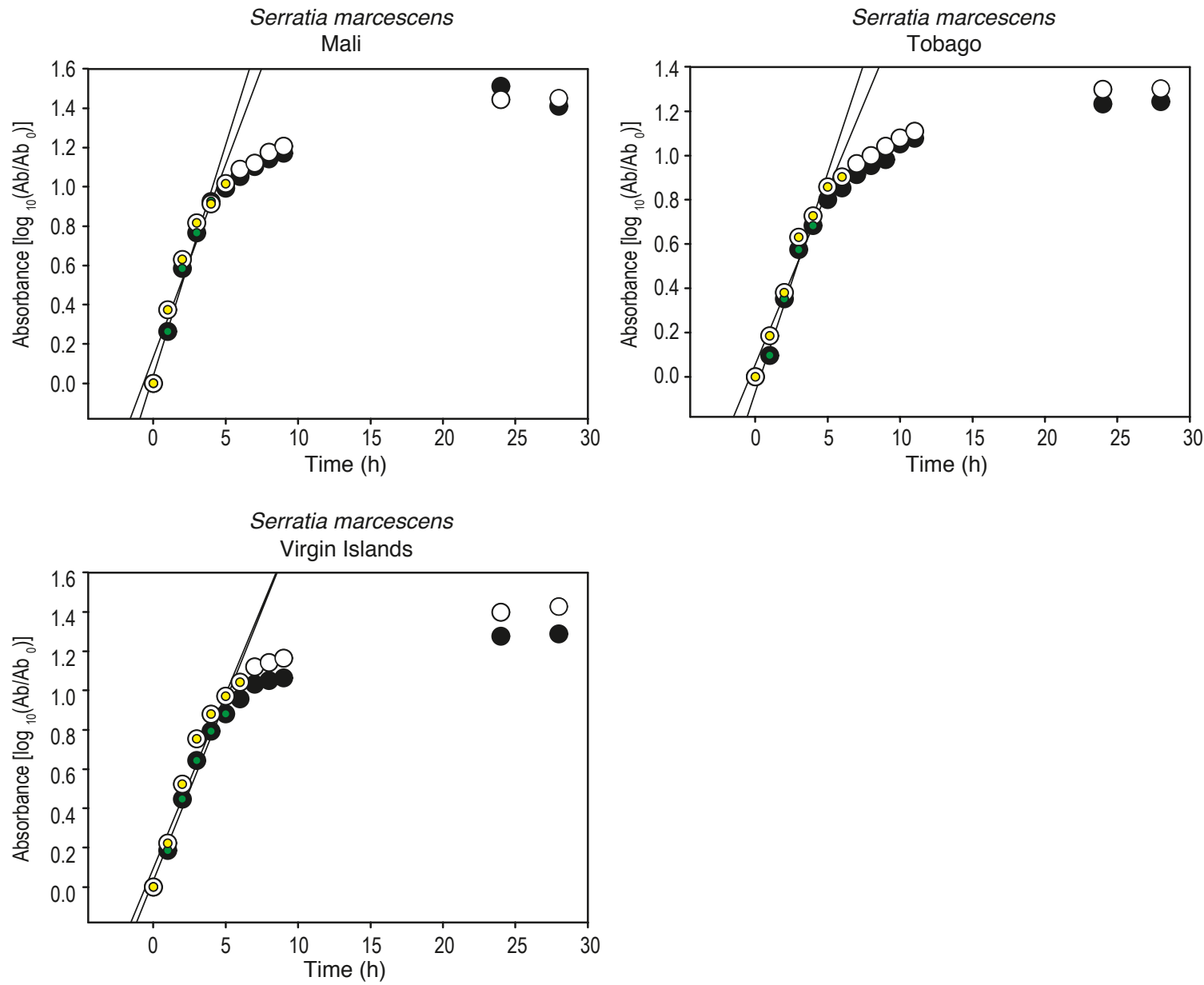

Figure 3. The effect of dust addition on the growth of Serratia marcescens by site. The black symbols represent data for the filter control (i.e., no dust addition) culture and the white symbols represent data from the experimental (i.e., dust addition) culture. Those symbols with a colored center are the data values used in the calculations of the linear regression models. 

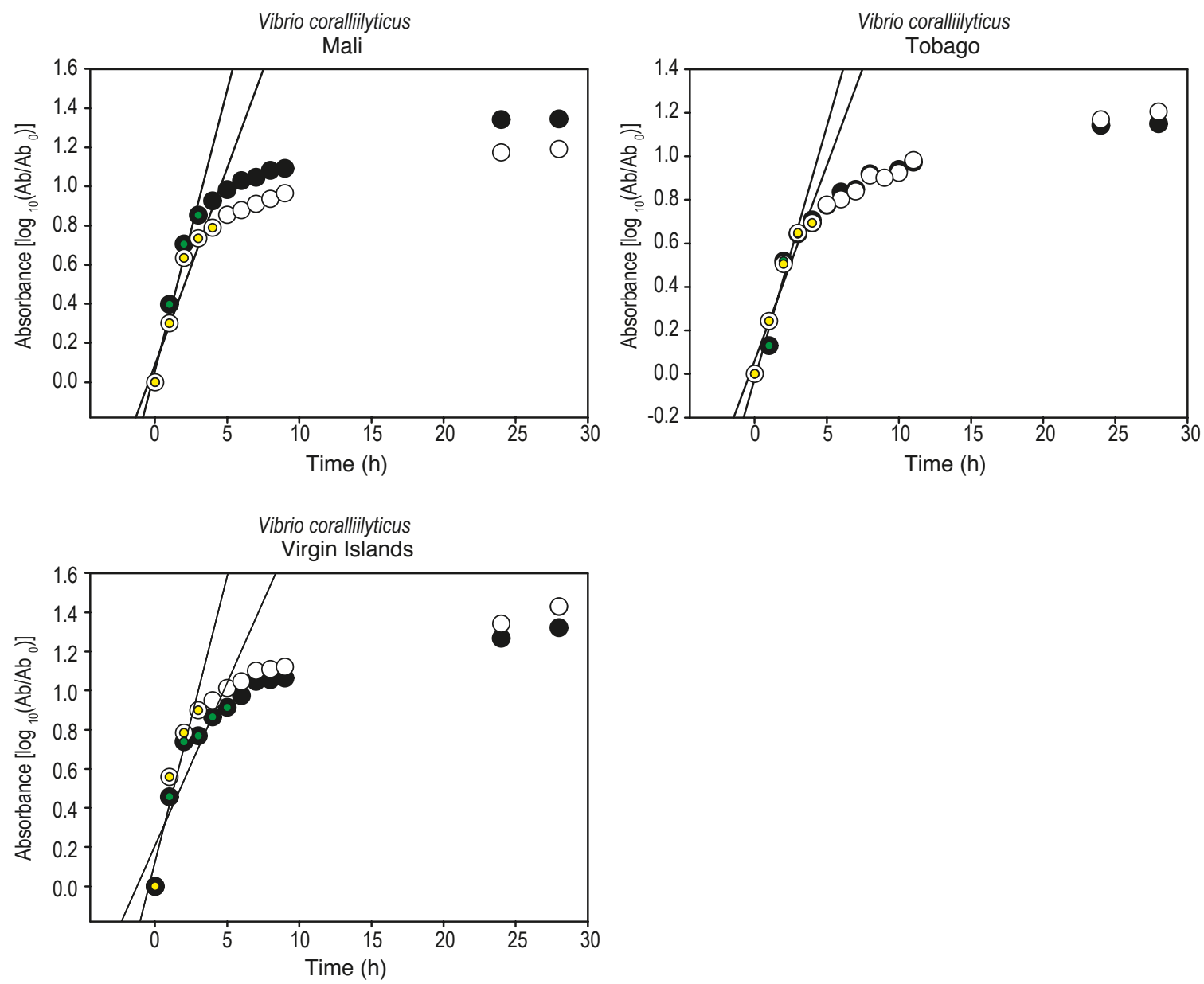

Figure 4. The effect of dust addition on the growth of Vibrio coralliilyticus by site. The black symbols represent data for the filter control (i.e., no dust addition) culture and the white symbols represent data from the experimental (i.e., dust addition) culture. Those symbols with a colored center are the data values used in the calculations of the linear regression models. 


\section{References Cited}

Ben-Haim, Y., Thompson, F.L., Thompson, C.C., Cnockaert, M.C., Hoste, B., Swings, J., and Rosenberg, E., 2003a, Vibrio coralliilyticus sp. nov., a temperature-dependent pathogen of the coral Pocillopora damicornis: International Journal of Systematic and Evolutionary Microbiology, v. 53, p. 309-315.

Ben-Haim, Y., Zicherman-Keren, M., and Rosenberg, E., 2003b, Temperature-regulated bleaching and lysis of the coral Pocillopora damicornis by the novel pathogen Vibrio coralliilyticus: Applied and Environmental Microbiology, v. 69, p. 4236-4242.

Briggs, P.H., and Meier, A.L., 2002, The determination of forty-two elements in geological materials by ICP-MS, chap. I of Taggart, J.E, Jr., ed., Analytical methods for chemical analysis of geologic and other materials: U.S. Geological Survey Open-File Report 2002-223, p. T20.

Bruno, J.F., Petes, L.E., Harvell, C.D., and Hettinger, A., 2003, Nutrient enrichment can increase the severity of coral diseases: Ecology Letters, v. 6, p. 1056-1061.

Castillo, S., Moreno, T., Querol, X., Alastuey, A., Cuevas, E., Herrmann, L., Mounkaila, M., and Gibbons, W., 2008, Trace element variation in size-fractionated African desert dusts: Journal of Arid Environments, v. 72, p. 1034-1045.

Denner, E.B.M., Smith, G., Busse, H.J., Schumann, P., Narzt, T., Polson, S.W., Lubitz, W., and Richardson, L.L., 2003, Aurantimonas coralicida gen. nov., sp. nov., the causative agent of white plague type II on Caribbean scleractinian corals: International Journal of Systematic and Evolutionary Microbiology, v. 53, p. 1115-1122.

Fry, J., 1993, Bivariate regression, in Biological data analysis; A practical approach: New York, IRL Press, p. 81-126.

Garrison, V.H., Shinn, E.A., Foreman, W.T., Griffin, D.W., Holmes, C.W., Kellogg, C.A., Majewski, M.S., Richardson, L.L, Ritchie, K.B., and Smith, G.W., 2003, African and Asian dust; From desert soils to coral reefs: Bioscience, v. 53, p. 469-480.

Gillies, J.A., Nickling, W.G., and McTainsh, G.H., 1996, Dust concentrations and particle-size characteristics of an intense dust haze event; inland delta region, Mali, West Africa: Atmospheric Environment, v. 30, p. 1081-1090.

Harvard Biosafety, 2009, Methods of decontamination: Cambridge, President and Fellows of Harvard College.

Hayes, M.L., Bonaventura, J., Mitchell, T.P., Prospero, J.M., Sherman, B.H., Shinn, E.A., Van Dolah, F., and Barber, R.T., 2001, How are climate and marine biological outbreaks functionally related?: Hydrobiologia, v. 460, p. 213-220.

Kushmaro, A., Banin, E., Loya, Y., Stackebrandt, E., and Rosenberg, E., 2001, Vibrio shiloii sp. nov., the causative agent of bleaching of the coral Oculina patagonica: International Journal of Systematic and Evolutionary Microbiology, v. 51, p. 1383-1388.

McTainsh, G.H., Nickling, W.G., and Lynch, A.W., 1997, Dust deposition and particle size in Mali, West Africa: Catena, v. 29, p. 307-322. 
Moreno, T., Querol, X., Castillo, S., Alastuey, A., Cuevas, E., Herrmann, L., Mounkaila, M., Elvira, J., and Gibbons, W., 2006, Geochemical variations in aeolian mineral particles from the Sahara-Sahel dust corridor: Chemosphere, v. 65, p. 261-270.

Morman, S.A., Garrison, V.H., and Plumlee, G.S., 2013, Trace metals in Saharan dust: The use of in vitro bioaccessibility extractions to assess potential health risks in a dustier world: Chapter 8 , in McConnell, L., Dachs, J., and Hapeman, C.J., eds., American Chemical Society Symposium Series 1149 Occurrence, fate and impact of atmospheric pollutants on environmental and human health: American Chemical Society.

Muhs, D.R., Budahn, J.R , Prospero, J.M., and Carey, S.N., 2007, Geochemical evidence for African dust inputs to soils of western Atlantic islands; Barbados, the Bahamas, and Florida: Journal of Geophysical Research, v. 112, no. F2, June 2007. (Also available at http://dx.doi. org/10.1029/2005JF000445.)

Oliver, J.D. and Colwell, R.R., 1973, Extractable lipids of gram-negative marine bacteria: Phospholipid composition: Journal of Bacteriology, v. 114, p. 897-908.

Patterson, K.L., Porter, J.W., Ritchie, K.B., Polson, S.W., Mueller, E., Peters, E.C., Santavy, D.L., and Smith, G.W., 2002, The etiology of white pox, a lethal disease of the Caribbean elkhorn coral, Acropora palmate: Proceedings of the National Academy of Sciences of the United States of America, v. 99, p. 8725-8730.

Perry, K.D., Cahill, T.A., Eldred, R.A., and Dutcher, D.D., 1997, Long-range transport of North African dust to the eastern United States: Journal of Geophysical Research, v. 102, p. 11,225-11,238.

Prospero, J.M., Glaccum, R.A., and Nees, R.T., 1981, Atmospheric transport of soil dust from Africa to South America: Nature, v., 289, p. 570-572.

Prospero, J.M., and Nees, R.T., 1986, Impact of the North African drought and El Niño on mineral dust in the Barbados trade winds: Nature, v. 320, p. 735-738.

Remily, E.R., and Richardson, L.L., 2006, Ecological physiology of a coral pathogen and the coral reef environment: Microbial Ecology, v. 51, p. 345-352.

Shinn, E.A., Smith, G.W., Prospero, J.M., Betzer, P., Hayes, M.L., Garrison, V.H., and Barber, R.T., 2000, African dust and the demise of Caribbean coral reefs: Geophysical Research Letters, v. 27, p. 3029-3032.

Talbot, R.W., Harris, R.C., Browell, E.V., Gregory, G.L., Sebacher, D.I., and Beck, S.M., 1986, Distribution and geochemistry of aerosols in the tropical North Atlantic troposphere; Relationship to Saharan dust: Journal of Geophysical Research, v. 91, p. 5173-5182.

Thompson, F.L., Barash, Y., Sawabe, T., Sharon, G., Swings, J., Rosenberg, E., 2006, Thalassomonas loyana sp. nov., a causative agent of the white plague-like disease of corals on the Eilat coral reef: International Journal of Systematic and Evolutionary Microbiology, v. 56, p. 365-368.

Toren, A., Landau, L., Kushmaro, A., Loya, Y., Rosenberg, E., 1998, Effect of temperature on adhesion of Vibrio strain AK-1 to Oculina patagonica and on coral bleaching: Applied Environmental Microbiology, v. 64, p. 1379-1384. 